\title{
shRNA-WT1 Potentiates Anticancer Effects of Gemcitabine and Cisplatin Against B16F10 Lung Metastases In Vitro and In Vivo
}

\author{
PABLO ZAPATA-BENAVIDES, FERNANDA GUADALUPE THOMPSON-ARMENDARIZ, \\ MARIELA ARELLANO-RODRÍGUEZ, MOISÉS ARMIDES FRANCO-MOLINA, EDGAR MENDOZA-GAMBOA, \\ SANTIAGO SAAVEDRA-ALONSO, JOSÉ LUIS ZACARIAS-HERNÁNDEZ, \\ LAURA MARÍA TREJO-AVILA and CRISTINA RODRÍGUEZ-PADILLA
}

Department of Microbiology and Immunology, Faculty of Biological Sciences, University Autonomous of Nuevo Leon (UANL), San Nicolas de los Garza, Mexico

\begin{abstract}
Background/Aim: High expression level of Wilm's tumor gene (WT1) in several types of tumors appears to confer disruption of apoptosis and resistance to chemotherapeutic drugs, and correlate with poor outcome. The aim of this work was to determine if down-regulation of WT1 expression results in decreased cell proliferation and the increased action of different types of drugs, both in vitro in B16F10 cells, and in vivo in C57BL/6 mice. Materials and Methods: Inhibition of cell proliferation by short hairpin RNA against WT1 (shRNAWT1), cisplatin, and gemcitabine in B16F10 cells in vitro was determined by the MTT assay and analysis of clonogenic survival. The apoptosis rate was determined by flow cytometry for annexin- $V$-fluorescein isothiocyante and propidium iodide. Results: Compared to treatment with shRNA-WT1 alone, treatment with shRNA-WT1 in combination with drugs had a synergistic inhibitory effect on B16F10 cell proliferation, particularly for the combination of cisplatin and gemcitabine at their $25 \%$ cytotoxic concentrations in vitro. Furthermore, mice treated with shRNA-WT1 in combination with cisplatin and gemcitabine were protected in the same way as those treated with the drugs alone, but were in better physical condition. Conclusion: Decreased WT1 expression induces cell death and potentiates the action of anticancer drugs by inducing synergistic effects both in vitro and in vivo, which may be an attractive strategy in lung cancer therapy.
\end{abstract}

This article is freely accessible online.

Correspondence to: Dr. Pablo Zapata-Benavides, Department of Microbiology and Immunology, Faculty of Biological Sciences, University Autonomous of Nuevo Leon (UANL), Unit C, Pedro de Alba S/N, San Nicolás de los Garza, Nuevo León, 66450, México. Tel: +52 8183294115, Fax: +52 8183524212, e-mail: pablozapata@hotmail.com; pablo.zapatabn@uanl.edu.mx

Key Words: WT1, shRNA, gemcitabine, cisplatin, cancer.
The Wilm's tumor gene (WT1) encodes a transcription factor with zinc finger motifs that modulates the expression of several genes involved in cell proliferation (1) and apoptosis (2). WT1 expression is observed in some type of malignancies, such as leukemia and solid tumors, including breast cancer (3), colon (4), ovarian (5), melanoma (6) and lung cancer (7). High levels of WT1 mRNA have been correlated with poor prognosis in patients with breast cancer and leukemia (8-10), as well as greater drug resistance (11) and worse survival compared to patients with low levels of WT1 mRNA (10). For this reason, WT1 is considered a good target for anticancer therapy (12). The silencing of genes involved in proliferation and apoptosis are an attractive strategy for the development of anticancer therapies (13-15), and for sensitizing tumor cells to chemotherapy (14). It has been observed that silencing genes such as B-cell lymphoma 2 (BCL2) and BCL-xL sensitizes cisplatin-resistant cells (16, 17). RNA therapeutics, the design and dosage of which can be tailored to individual patients based on their mRNA expression levels of target genes, might represent the next generation of personalized medicine (18).

Down-regulation of WT1 protein expression by antisense oligodeoxynucleotides and RNA interference in different types of cell lines $(1,19-21)$ was found to result in cell growth inhibition, as well as modified expression of proteins involved in the cell cycle, such as cyclin D1, and those involved in apoptosis, such as caspase-3 and poly-ADPribose polymerase $(1,19)$. In vivo, Zamora et al. observed that delivery of complexes of small hairpin RNA plasmid against WT1 (shRNA-WT1) with polyethyleneimine (PEI) by an aerosol system to lungs of mice with B16F10 lung metastases resulted in a reduction in the number and size of lung tumor foci and the number and size of tumor blood vessels, suggesting reduced angiogenesis (22). Furthermore, it has been shown that WT1 silencing by shRNA synergized with chemotherapeutic agents and induced chemosensitization to doxorubicin and cisplatin in B16F10 
murine melanoma cells (23). Cisplatin and gemcitabine are among the most widely used cytotoxic agents for cancer therapy to treat various solid tumors such as ovarian, nonsmall cell lung, pancreatic, and breast cancer (24-27). The combination of gemcitabine with cisplatin is an attractive therapeutic strategy because of its favorable toxicity profile, and preclinical studies have suggested that gemcitabine may have an additive or synergistic effect when combined with cisplatin (26).

In this study, we analyzed the effect of shRNA-WT1/PEI complexes administered via aerosol on the sensitization to cisplatin and gemcitabine alone versus in combination, both in vitro in $\mathrm{B} 16 \mathrm{~F} 10$ cells and in vivo in mice with $\mathrm{B} 16 \mathrm{~F} 10$ lung metastases.

\section{Materials and Methods}

Animal model. Eight-week-old female C57BL/6 mice were purchased from Harlan Laboratory (Coyoacan, DF, Mexico). Four mice in each group were used in the assay and caged under controlled room temperature, humidity, and light (12/12 h light-dark cycle) with water and food ad libitum. The experimental protocols used in this study were approved by the Institutional Animal Care and Use Committee of the Faculty of Biological Sciences, UANL (approval number 0032/2017).

Cell lines and cell cultures. The B16F10 murine melanoma cell line was obtained from the American Type Culture Collection (Manassas, VA, USA), and cultured and maintained in Dulbecco's modified Eagle's medium (DMEMF-12) (Life Technologies, Invitrogen, Burlington, ON, Canada), supplemented with $10 \%$ fetal bovine serum, $100 \mathrm{U} / \mathrm{ml}$ of penicillin, and $100 \mu \mathrm{g} / \mathrm{ml}$ of streptomycin (Gibco, Grand Island, NY, USA). Cells were incubated in a humidified chamber at $37^{\circ} \mathrm{C}$ in an atmosphere of $95 \% \mathrm{O}_{2}$ and $5 \% \mathrm{CO}_{2}$.

Transfection of shRNA-WT1. B16F10 cells were seeded in a 96-well plate for $24 \mathrm{~h}$. After that, the B16F10 cells were transfected with the small hairpin RNA plasmid to produce RNAi against WT1 (shRNA-WT1), or with the plasmid enhanced green fluorescent protein (pEGFP-N2) as a negative control (Clontech Palo Alto, CA, USA) using the cationic polymer PEI (25-kDa branched form; Aldrich, Milwaukee, IL, USA) and incubated at $37^{\circ} \mathrm{C}, 5 \% \mathrm{CO}_{2}$ for $72 \mathrm{~h}$. The PEI-DNA complex was generated as described by Zamora-Avila et al. (22). Thereafter, a 3-(4,5-dimethylthazol-2-yl)2,5-diphenyl tetrazolium bromide (MTT) assay was performed. Twenty microliters of MTT solution at $5 \mathrm{mg} / \mathrm{ml}$ was added to each well and incubated at $37^{\circ} \mathrm{C}$ for $1 \mathrm{~h}$. The absorbance at $570 \mathrm{~nm}$ was measured using a microplate reader (Microplate Autoreader EL311; BioTek Instruments Inc., Winooski, VA, USA). Data are presented as the mean percentage of cell viability $\pm \mathrm{SD}$.

Chemosensitivity assay. B16F10 cells were cultured in 96-well plates for $24 \mathrm{~h}$ and then transfected with shRNA-WT1. After $24 \mathrm{~h}$, the cells were treated with several concentrations of cisplatin $(2.5,5,7.5,10$ $12.5,15 \mathrm{ng} / \mu \mathrm{l})$ or gemcitabine $(0.5,1.5,10,50,100 \mathrm{pg} / \mu \mathrm{l})$. After 48 $\mathrm{h}$ of incubation, cell viability was determined using MTT assay. The $50 \%$ cytotoxic concentration $\left(\mathrm{CC}_{50}\right)$ was calculated using $\log$ (inhibitor) versus response (variable slope) CompuSyn software (ComboSyn, Inc, Paramus, NJ, USA). To determine the combined effects of cisplatin and gemcitabine on $\mathrm{B} 16 \mathrm{~F} 10$ cells, different concentrations of drugs were tested, corresponding to $\mathrm{CC}_{12.5}, \mathrm{CC}_{25}$, and $\mathrm{CC}_{37.5}$, on cells transfected with shRNA-WT1 and p-EGFP-N2. The analysis of the combinatorial effect, based on the equation for the median effect and the normalized isobologram, was performed using CompuSyn software.

Colony formation assay. B16F10 cells were seeded in 6-well plates at 200 and 500 cells/well, for control and treatments, respectively. After $24 \mathrm{~h}$, cells were transfected with shRNA-WT1; $24 \mathrm{~h}$ after transfection, cells were treated with a dose corresponding to the $\mathrm{CC}_{50}$ of cisplatin and gemcitabine, and incubated in culture medium for 14 days. The cells were then washed with phosphate-buffered saline (PBS), fixed with $100 \%$ methanol, and stained with $0.1 \%$ crystal violet. To determine the number of colony-forming units, the cells were observed under a stereoscopic microscope. Colonies consisting of more than 50 cells were counted.

RNA isolation and RT-PCR. Total RNA from B16F10 cells was isolated using $1 \mathrm{ml}$ of Trizol reagent (Life Technologies, Carlsbad, CA, USA) according to the manufacturer's instructions. RNA concentration and integrity were determined by measuring the absorbance at $260 \mathrm{~nm}$. The cDNA was performed using $5 \mu \mathrm{g}$ of total RNA, $200 \mathrm{U}$ of Superscript III, and $0.5 \mu \mathrm{g}$ of oligo dT (12-18) under the following conditions: $42^{\circ} \mathrm{C}$ for $90 \mathrm{~min}$, followed by heating at $70^{\circ} \mathrm{C}$ for $10 \mathrm{~min}$. The cDNA obtained was amplified using Taq DNA polymerase (Life Technologies) and $W t 1$ primers: 5'-AACGCCCCTTCATGTGTGC-3' and 5'-GCTGGTCTGAACGAGAAAACCTTC-3' to amplify a fragment of $150 \mathrm{bp}$. PCR was performed according to Laux et al. (28). For $B c l 2$, the primers used were 5'-TCATGTGTGTGGAGAGCGGT CCAA-3' and 5'-GTGTGTGTCTGTCTGTGTGTGTA-3' to amplify a fragment of $422 \mathrm{bp}$. For glyceraldehyde-3-phosphate dehydrogenase (Gapdh), the primers: 5'-GTGGGGCGCCCCAG GCACCA-3' and 'GTGGGGCGCCCCAGGCACCA-3' were used to generate a 452-bp product. PCR products were analyzed by electrophoresis on a $0.8 \%$ agarose gel and visualized by ethidium bromide staining.

Flow cytometric analysis of apoptosis. The apoptosis assay was performed using ApoTargetTM annexin V-FITC kit (BioSource International, Inc., Camarillo, CA, USA) and following the manufacturer's protocol. Briefly, B16F10 cells were seeded at a density of $5 \times 10^{5} /$ well in a 6 -well plate. After $24 \mathrm{~h}$ of adherence, cells were transfected with the shRNA-WT1. At $24 \mathrm{~h}$ posttransfection, the cells were exposed to treatments $(0.001 \mathrm{ng} / \mu \mathrm{l}$ gemcitabine or $0.1 \mathrm{ng} / \mu \mathrm{l}$ cisplatin) and then incubated for $48 \mathrm{~h}$. The cells were then trypsinized, washed twice with cold PBS and suspended in $100 \mu \mathrm{l}$ of binding buffer $(0.1 \mathrm{M}$ Hepes/NaOH pH 7.4, $1.4 \mathrm{M} \mathrm{NaCl}, 25 \mathrm{mM} \mathrm{CaCl}_{2}$ ), supplemented with $0.5 \mu \mathrm{l}$ of Annexin V-FITC and $0.5 \mu \mathrm{l}$ of propidium iodide (PI). The cell suspensions were gently vortexed and incubated for $20 \mathrm{~min}$ at $4^{\circ} \mathrm{C}$ in the dark, and then measurements were acquired on a FACSCalibur flow cytometer BD Accuri C6 (Becton Dickinson Biosciences, Ann Arbor, MI, USA). Data were analyzed using CellQuest WinMDI software (BD Biosciences, San Jose, CA, USA).

Animal model. Lung metastases were produced by intravenous administration of $\mathrm{B} 16 \mathrm{~F} 10$ cells. For this, $5 \times 10^{5}$ cells (passages $3-$ 12), prepared in $150 \mu \mathrm{I}$ medium without serum, were injected per 


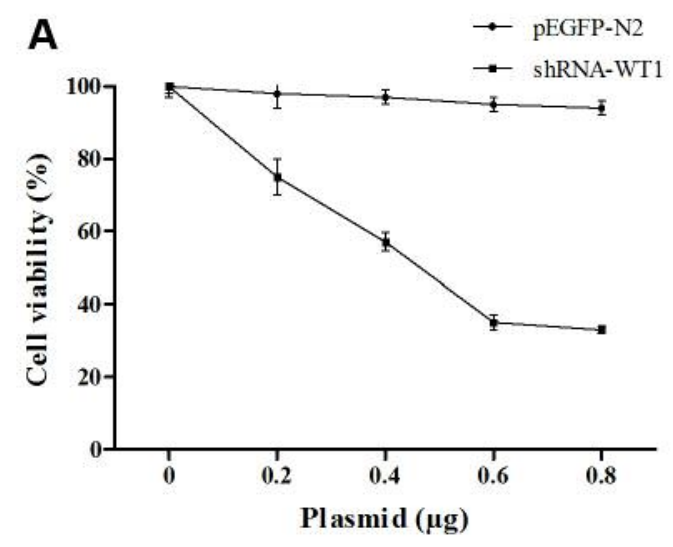

B

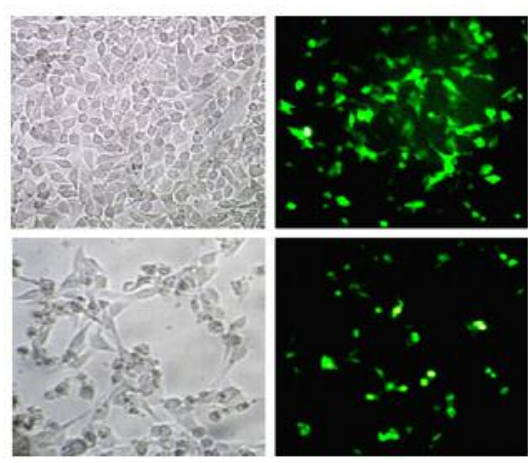

pEGFP-N2

shRNA-WT1

Figure 1. Wilm's tumor gene (WT1) knockdown inhibits proliferation of B16F10 cells. A: Inhibitory effect of short hairpin RNA against WT1 (shRNAWT1) on B16F10 cells, determined by the MTT assay. B: Assessment of shRNA transfection efficiency and cytotoxicity by fluorescence microscopy. B16F10 cells were transfected with plasmid enhanced green fluorescent protein (pEGFP-N2) as control and shRNA-WT1, and cells were visualized under a visible light and fluorescence light microscopy.

mouse through the tail vein. Lung metastases were detected within 7 days after injection (22).

Preparation of PEI-DNA complexes. A stock solution of PEI (25 $\mathrm{kDa}$ branched form; Aldrich, Milwaukee, IL, USA) was prepared at a concentration of $4.3 \mathrm{mg} / \mathrm{ml}(0.1 \mathrm{M}$ in nitrogen $)$ in water. The DNA had $3 \mathrm{nmol}$ phosphate per microgram and $1 \mathrm{ml}$ of the $0.1 \mathrm{M}$ PEI solution had $100 \mathrm{nmol}$ of amine nitrogen. The resulting charge ratio was expressed as the ratio of PEI nitrogen to DNA phosphorus (N/P). A 10:1 N/P was used for the experiments, which corresponds to a $1.29: 1 \mathrm{PEI} / \mathrm{DNA}$ weight ratio (22).

Delivery of PEI-DNA complexes by aerosol. A nose exposure chamber was used for aerosol delivery of shRNA-WT1 15 four mice using a Pulmo-Aide Model 5650D compressor, which includes a Micro-Mist Nebulizer (115v) (DeVilbiss Health Care Corp., Somerset, PA, USA) (22). Beginning 2 days after injection of B16F10 melanoma cell line, mice were treated three times at 6-day intervals with $25 \mu \mathrm{g}$ of PEI-DNA complexes per mouse in a final volume of $2 \mathrm{ml}$, with four mice per experimental group. Mice in the untreated control group were aerosolized with PEI-pEGFP-N2 complex (Clontech).

Drugs administration in vivo. Mice were treated with two applications of each drug intraperitoneally, at a dose of $60 \mathrm{mg} / \mathrm{kg}$ of gemcitabine and $3 \mathrm{mg} / \mathrm{kg}$ of cisplatin. The drugs were administered 1 day after the first two shRNA-WT1 aerosolizations. This resulted in the following experimental groups: Control (-): mice without tumor; Control $(+)$ : mice with tumor but not treated; cisplatin treatment; gemcitabine treatment; shRNA-WT1; shRNAWT1 plus cisplatin; shRNA-WT1 plus gemcitabine; sh-RNA-WT1 plus cisplatin and gemcitabine treatment.

Evaluation of tumor burden. The mice were monitored until their death. The lungs were isolated, washed with PBS, weighed, and examined under an inverted microscope. Tumors that grew contiguous to the lung were considered to be part of the lung for the purpose of measuring lung weight.
Statistical analysis. The combinatorial effect was calculated using CompuSyn software, based on the equation of the median effect and the normalized isobologram. The results are presented as the mean \pm SD. Comparisons were performed in Graphpad Prism software version 7 (GraphPad, San Diego, CA, USA) using analysis of variance with post Tukey's test, and differences with a $p$-value of 0.05 or less were considered to be significant.

\section{Results}

Inhibition of WT1 with shRNA sensitizes B16F10 cells to gemcitabine and cisplatin. Inhibition of cell viability was analyzed to determine the functionality of the shRNA-WT1 plasmid (22); the cell growth curve indicates that the proliferation rate was inhibited in a dose-dependent manner compared to control cells, as shown in Figure 1A. Fluorescence microscopy analysis after $72 \mathrm{~h}$ of transfection showed a drastic reduction in cell proliferation, compared with cells transfected with the pEGFP-N2 control plasmid (Figure 1B).

In order to determine chemosensitization, cells were transfected with $\mathrm{CC}_{50}$ shRNA-WT1, and $24 \mathrm{~h}$ later were treated with different concentrations of cisplatin and gemcitabine for $48 \mathrm{~h}$. The $\mathrm{CC}_{50}$ value for gemcitabine alone was $0.05 \mathrm{ng} / \mu \mathrm{l}$, and that for the combination of gemcitabine with shRNA-WT1 was $0.013 \mathrm{ng} / \mu \mathrm{l}$; treatment with gemcitabine-cisplatin and gemcitabine-cisplatin-shRNA-WT1 had greater effect, with $\mathrm{CC}_{50}$ values of 0.005 and $0.001 \mathrm{ng} / \mu \mathrm{l}$, respectively, which represent a decrease of 10-fold and 50-fold compared to the value for gemcitabine alone (Figure $2 \mathrm{~A}$ ).

On the other hand, the $\mathrm{CC}_{50}$ value was $10 \mathrm{ng} / \mu \mathrm{l}$ for cisplatin alone, $2.5 \mathrm{ng} / \mu \mathrm{l}$ for the combination of cisplatinshRNA-WT1, and $1 \mathrm{ng} / \mu \mathrm{l}$ for the combination of cisplatingemcitabine-shRNA-WT1, which represents a 10-fold 

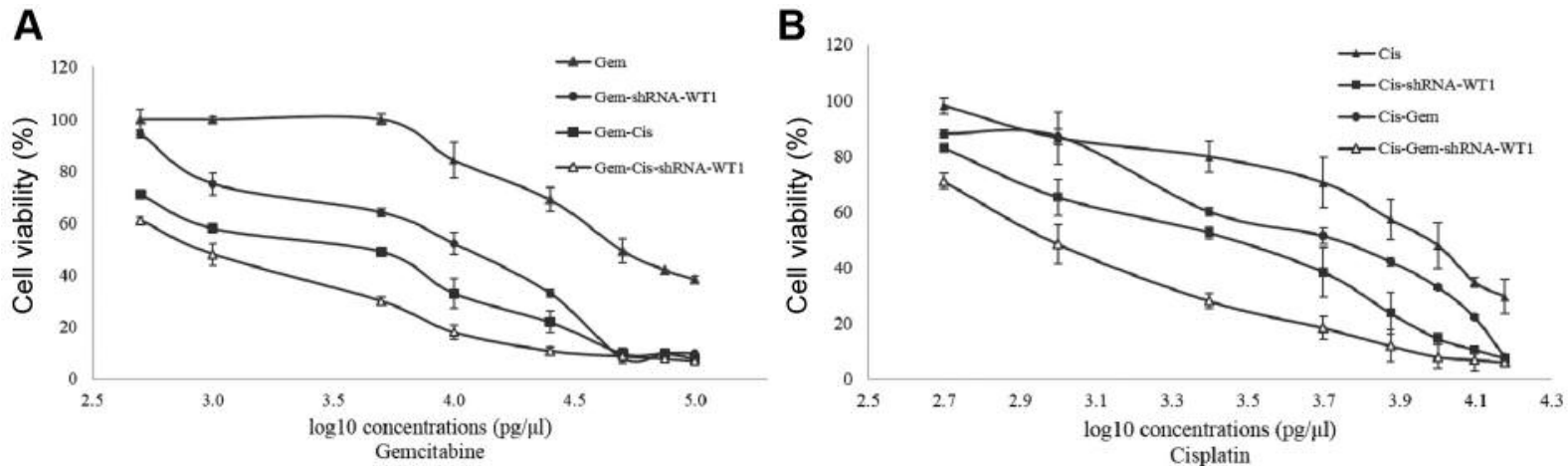

Figure 2. Dose-response curve for the B16F10 cell line at $72 \mathrm{~h}$ of treatment with different concentrations of gemcitabine (Gem; A), and cisplatin (Cis; B) alone, in combination, and with $50 \%$ cytotoxic concentration $\left(C C_{50}\right)$ doses of short hairpin RNA against Wilm's tumor gene (shRNA-WT1).

Table I. Effects of the combination of small hairpin RNA against Wilm's tumor gene (shRNA-WT1) with the chemotherapeutic drugs cisplatin and gemcitabine on B16F10 murine melanoma cells in vitro.

\begin{tabular}{lcccc}
\hline Combination of treatments & Cisplatin $(\mathrm{pg} / \mu \mathrm{l})$ & Gemcitabine $(\mathrm{pg} / \mu \mathrm{l})$ & Cytotoxic effect $(\%)$ & Effect \\
\hline $\mathrm{C}_{37.5}+\mathrm{G}_{12.5}$ & 6000 & 12.5 & $69.93 \pm 3.9$ & Synergism \\
$\mathrm{C}_{25}+\mathrm{G} 25$ & 4000 & 25 & $86.13 \pm 2.1$ & Synergism \\
$\mathrm{C}_{12.5}+\mathrm{G}_{37.5}$ & 2000 & 37.5 & $73.65 \pm 5.4$ & Synergism \\
$\mathrm{CR}_{37.5}+\mathrm{GR}_{12.5}$ & 1800 & 1.9 & $87.75 \pm 6.6$ & Synergism \\
$\mathrm{CR}_{25}+\mathrm{GR}_{25}$ & 1200 & 3.7 & $98.21 \pm 3.0$ & Synergism \\
$\mathrm{CR}_{12.5}+\mathrm{GR}_{37.5}$ & 600 & 5.5 & $80.03 \pm 5.5$ & Synergism \\
\hline
\end{tabular}

C\#: Cisplatin at \#\% cytotoxic concentration; G\#: gemcitabine at \#\% cytotoxic concentration; CR\#: cisplatin-treated shRNA-WT1-transfected cells at \#\% cytotoxic concentration; GR\#: gemcitabine-treated shRNA-WT1-transfected cells at \#\% cytotoxic concentration.

decrease with respect to cisplatin treatment alone. Cells treated with the cisplatin-shRNA-WT1 combination exhibited greater inhibition of cell proliferation compared with cisplatin-gemcitabine treatment (Figure 2B).

In order to determine the effect of the combination of cisplatin and gemcitabine on B16F10 cells, we tested different concentrations of each of the drugs, corresponding to their $\mathrm{CC}_{12.5}, \mathrm{CC}_{25}$, and $\mathrm{CC}_{37.5}$ values (Table I). Our evaluation, based on the equation of the median effect and the normalized isobologram (Figure 3), revealed the presence of a synergistic effect in the case of combinatorial treatment with both drugs (Figure 3A) and in the case of combinatorial treatment with both drugs and shRNA-WT1 (Figure 3B). The greatest cytotoxic effects were observed for the combination of shRNA-WT1 with $\mathrm{CC}_{25}$ doses of both drugs.

WT1 silencing and gemcitabine and cisplatin reduce Bcl2 expression in B16F10 cells. WT1 expression was observed to be lower in $\mathrm{B} 16 \mathrm{~F} 10$ cells that were transfected with shRNA-WT1 alone or in combination with the drugs, but higher in gemcitabine-treated cells, whereas the converse was seen with respect to $B c l 2$ expression (Figure 4).
WT1 silencing and gemcitabine and cisplatin reduce clonal formation of B16F10 cells. A clonogenic assay was carried out in order to examine the effect of shRNA-WT1 alone and combined with cisplatin and gemcitabine on the ability of B16F10 cells to form colonies (Figure 5). The results indicate treatment with shRNA-WT1 reduced the number of colonies formed by $38.27 \%$ that of the untreated control, whereas the combination of shRNA-WT1 and gemcitabine reduced the colony number by $57.6 \%$, and shRNA-WT1cisplatin treatment reduced the colony number by $88 \%$, while the combined treatment with gemcitabine-cisplatinshRNA-WT1 reduced the colony number by $97 \%$, in comparison to the untreated control cells. Overall, our results show that the colony-forming ability of the cells was inhibited by shRNA-WT1 alone and in combination with both drugs, which correlates with the inhibition of cell proliferation previously observed in this study.

WT1 silencing increases cellular apoptosis in B16F10 cells induced by gemcitabine and cisplatin. To determine whether the combined shRNA-WT1 and gemcitabine/cisplatin treatment had the ability to induce apoptosis, flow 

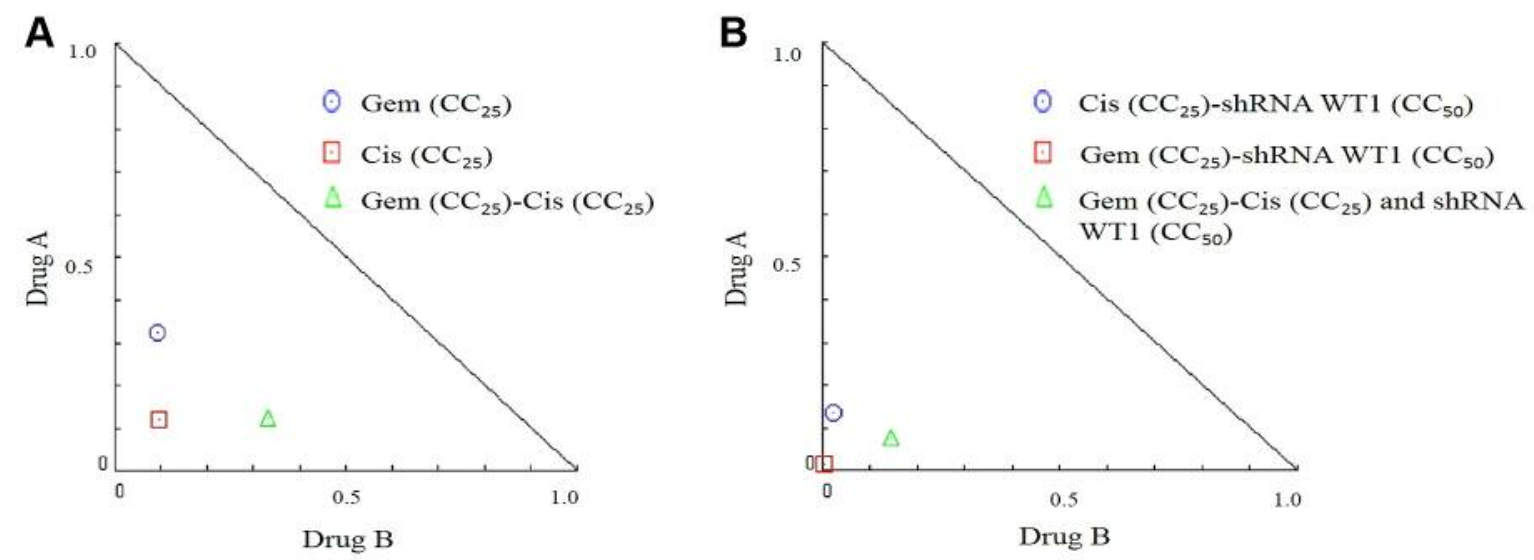

Figure 3. Isobologram plot of the effects of combinatorial treatment on B16F10 cells at $48 \mathrm{~h}$. A: Isobologram plot of B16F10 cells treated with $25 \%$ cytotoxic concentration $\left(C_{25}\right)$ of gemcitabine $(\mathrm{Gem})$ and cisplatin (Cis). B: Isobologram plot of B16F10 cells treated with CC 50 short hairpin RNA against Wilm's tumor gene (shRNA-WT1), and $C_{25}$ gemcitabine or cisplatin.

cytometry for annexin-V-FITC and PI dual labeling was performed. The assay revealed that the apoptosis rate was higher in cells treated with shRNA-WT1 cells $(14.8 \%)$, compared to untreated control cells $(1.9 \%)$, whereas cells treated with gemcitabine and cisplatin had specific PI labeling of $7.9 \%$ and $9.3 \%$, respectively, but were not labeled for annexin $\mathrm{V}$, which identifies apoptosis at an earlier stage. In the case of combinatorial treatment with shRNA-WT1 and drugs, a decrease in cell viability was observed, indicating that cell death by apoptosis predominated, with $21.2 \%$ of cells showing apoptosis for gemcitabine-shRNA-WT1, 18\% for cisplatin-shRNA WT1, and $22 \%$ for the triple treatment gemcitabine-cisplatinshRNA-WT1. Combinatorial treatment with shRNA-WT1 and the drugs showed very little staining with PI, compared to the higher percentage of PI-positive in cells when treated with the drugs alone, indicating a change in the type of cell death, preferentially apoptosis (Figure 6).

WT1 silencing and gemcitabine and cisplatin inhibit B16F10 lung metastases in vivo. In vivo assays were performed on C57BL/6 strain mice treated with different combinations of shRNA-WT1, gemcitabine, and cisplatin. Mice with an average initial weight of $20 \mathrm{~g}$ were injected with $5 \times 10^{5}$ B16F10 cells intravenously into the caudal vein, then treated following the proposed schedule, and the survival times and general health state of the mice were monitored during the experiment.

Figure 7A shows the survival curve up to 31 days from the start of the experiment. Upon data analysis, it was observed that compared to the untreated control group, mice in all treated groups had a higher percentage of survival and prolonged lifetime times. Survival rates of $100 \%$ were

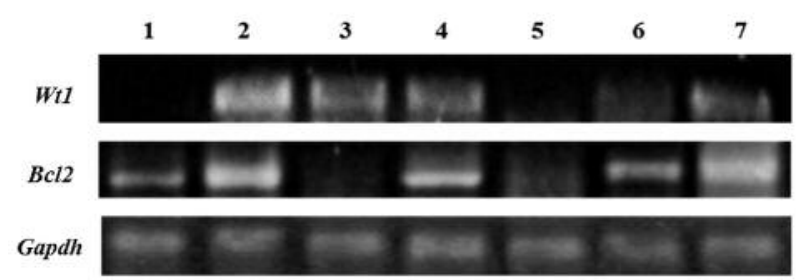

Figure 4. Expression of Wilm's tumor gene (Wt1) and B-cell lymphoma 2 (Bcl2) in B16F10 cells. Expression of Wt1 (150 bp), Bcl2 (422 bp), and glyceraldehyde-3-phosphate dehydrogenase (Gapdh) (452 bp) in B16F10 cells treated with short hairpin RNA against WT1 gene ( shRNA-WT1) at $50 \%$ cytotoxic concentration $\left(C C_{50}\right)$ (lane 1); gemcitabine $\left(C C_{25}\right)$ (lane 2); gemcitabine $\left(C C_{25}\right)$ and shRNA-WT1 $\left(C C_{50}\right)$ (lane 3$)$; cisplatin $\left(C C_{25}\right)$ with gemcitabine $\left(C C_{25}\right)$ (lane 4$)$; cisplatin $\left(C_{25}\right)$ with gemcitabine $\left(C_{25}\right)$ and shRNA-WT1 $\left(C C_{50}\right)$ (lane 5); as well as in untreated B16F10 cells (lane 6) and untreated K562 cells (lane 7).

observed in the groups treated with gemcitabine alone and with the combination of gemcitabine-cisplatin-shRNA-WT1, $80 \%$ survival was observed in mice treated with shRNAWT1 or cisplatin alone, or with cisplatin-shRNA-WT1 combination, and the lowest recorded survival (40\%) of treated mice was for those receiving the gemcitabineshRNA-WT1 combination, in comparison with the $20 \%$ survival rate observed in untreated control mice. Additionally, the physical appearance of animals that received both drugs plus shRNA-WT1 was better than that of animals that received the drugs alone, which showed a correlation with the percentage of survival and lifetime. Representative images of the lungs of mice from the different treatment groups are presented in Figure 7B. 


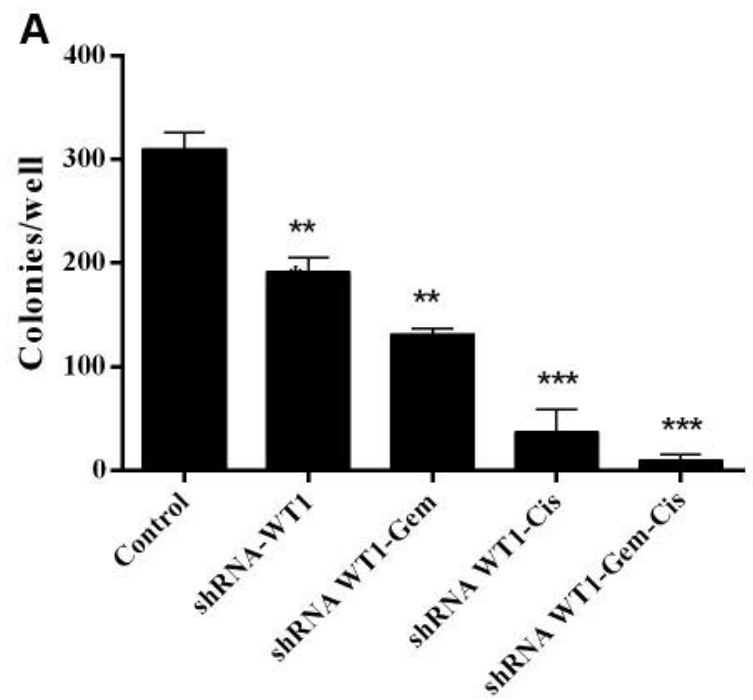

B

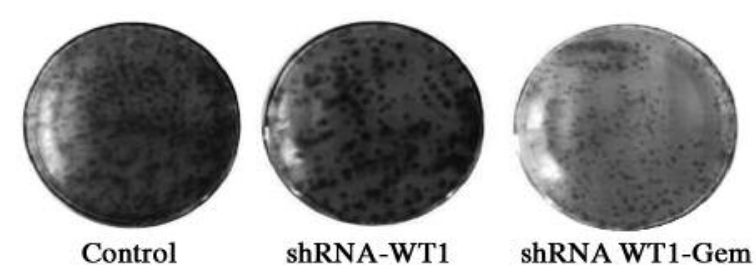

Figure 5. Analysis of clonogenic survival in B16F10 cells transfected with short hairpin RNA against Wilm's tumor gene (shRNA-WT1) and treated with gemcitabine (Gem) and cisplatin (Cis), alone and in combination. A: Representative images of clonogenic assays with different treatments. Cells were seeded into 6-well plates at a density of 200 cells per well (for controls) and 500 cells per well (for different treatments). Ten days later, the cells were fixed and the clonogenic assay was carried out. Data shown are the average of three independent experiments. B: The bar graph shows the colony number for each treatment relative to that of the untreated control cells.

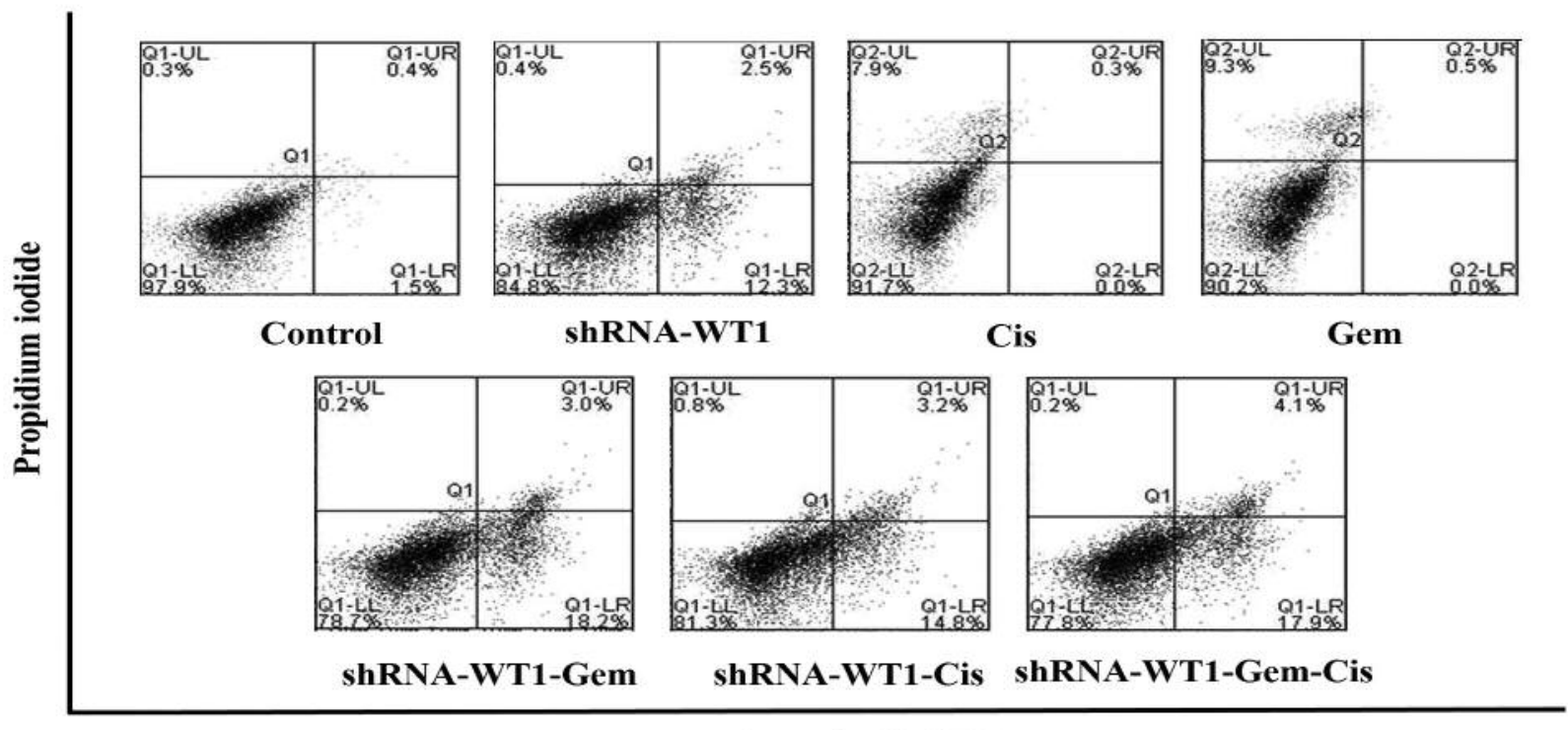

Annexin V-FITC

Figure 6. Wilm's tumor gene (WT1) knockdown enhances drug-induced cytotoxicity and apoptosis in B16F10 cells. Apoptosis rates in B16F10 cells transfected with short hairpin RNA against WT1 after 48 h of incubation with gemcitabine (Gem) and cisplatin (Cis) was determined by flow cytometry. The results are representative of three independent experiments.

\section{Discussion}

Lung cancer is one of the leading causes of death in the world; its late diagnosis and the inefficacy of available therapies render it difficult to cure. Standard treatment for cancer includes a combination of different chemotherapeutic agents $(29,30)$; however, these treatments have limited efficacy and exert significant toxic effects on healthy cells. 
A

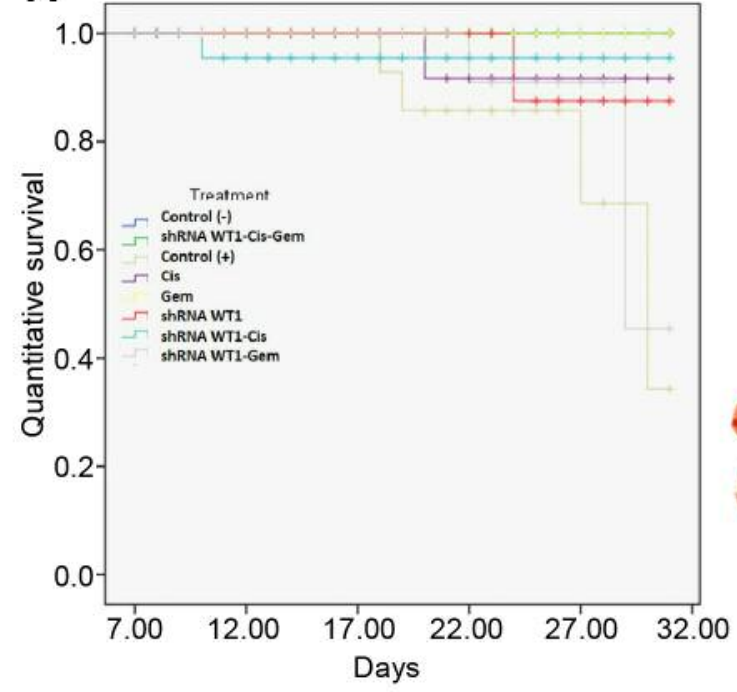

B



Control (-) ShRNA-WT1-Gem-Cis
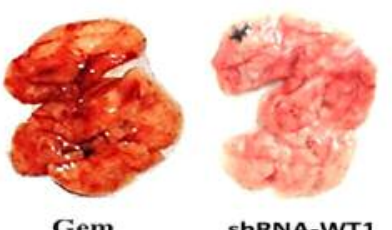

ShRNA-WT1

Gem

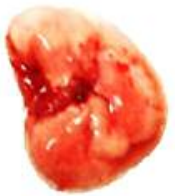

Cis

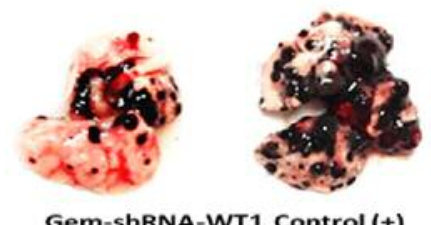

Gem-shRNA-WT1 Control (+)

Figure 7. Survival and tumors of mice bearing B16F10 tumors. A: Survival curves of B16F10 tumor-bearing mice treated with different combinations of gemcitabine (Gem), cisplatin (Cis) and short hairpin RNA against Wilm's tumor gene (shRNA-WT1). B: Images of lungs with pulmonary metastasis at the end of the experiment. Control (-): mice without tumor; Control (+): mice with tumor but not treated.

Tumor resistance to anticancer drugs occurs through many mechanisms, such as inactivation of apoptotic pathways (31, 32). Down-regulation of the expression of genes involved in cell proliferation or anti-apoptosis has been used to sensitize different tumor cells to chemotherapy (33). WT1 expression is essential for the proliferation of the B $16 \mathrm{~F} 10$ melanoma cell line, and its down-regulation induces apoptosis and chemosensitizes cells $(22,23)$.

The aerosol system has been used with the cationic polymer PEI for the administration of genes or antisense elements for the treatment of lung cancer. PEI-p53 complexes suppressed the establishment of lung metastases in a model of human osteosarcoma in nude mice with the SAOS-LM6 cell line (34), and in the B16F10 murine melanoma model in C57BL/6 mice (35). On the other hand, it was observed that the silencing of the WT1 gene using PEI-shRNA complexes by aerosol delivery inhibited the growth of B16F10 lung metastases (22).

Our previous results indicated that a shRNA targeted to WT1 chemosensitized B16F10 cells to doxorubicin and cisplatin in vitro (23). In this study, we analyzed whether this shRNA-WT1 can sensitize B16F10 cells to combined treatment with cisplatin and gemcitabine in vitro and in vivo. We observed a greater antiproliferative effect on cells treated with a combination of cisplatin and gemcitabine than on cells treated with each of these drugs alone in vitro. Synergistic effects were induced with combinations of different concentrations of cisplatin and gemcitabine in cells transfected with shRNA-WT1.
In cells that were treated in vitro with shRNA-WT1 alone or in combination with the drugs, WT1 expression decreased and was correlated with BCL2 expression. It has been reported that WT1 modulates the expression of BCL2, p21, and cyclin D, and suppresses p53 activity, which leads to resistance to chemotherapeutic compounds (23). BCL2 modulation by WT1 has been documented in different types of cancer cells $(36,37)$ and involves a direct interaction with the $\mathrm{P} 2$ region of the $B C L 2$ promoter (38). On the other hand, it has been observed that gemcitabine enhances WT1 expression in cholangiocarcinoma and human pancreatic cancer cells, sensitizing the cells to a WT1-specific T-cellmediated antitumor immune response $(39,40)$.

In the analysis in vivo, mice that received the triple combined treatment had no negative side-effects, and presented a healthy appearance.

In the survival analysis, mice from all treated groups had a higher percentage of survival and a prolonged lifetime, compared to the untreated control group. The survival rate was $100 \%$ in mice treated with gemcitabine and with the combination of both drugs and shRNA-WT1, and $80 \%$ in mice treated with shRNA-WT1 with and without cisplatin. In all the groups, survival time was directly related to the number of tumor foci found in the lungs of the mice. The strong correlation between in vitro and in vivo antitumor results, and the absence of side-effects with the combination cisplatin-gemcitabine-shRNA-WT1 in vivo suggest that this regimen might be an attractive strategy to effectively destroy aggressive WT1-expressing tumors. 
We demonstrated that treatment with PEI-shRNA-WT1 complexes induces inhibition of cell proliferation and sensitizes B16F10 cells to cisplatin and gemcitabine, causing a synergistic effect in vitro. In vivo, the aerosol delivery of PEI-shRNA-WT1 complexes potentiates the effect of cisplatin and gemcitabine and inhibits lung metastasis. In conclusion, WT1 silencing to sensitize tumor cells to different drugs may be an attractive strategy in lung cancer therapy.

\section{Competing Interests}

The Authors report no conflicts of interest in regard to this study.

\section{Author Contributions}

Formal analysis: Mariela Arellano-Rodríguez, Moisés Armides Franco-Molina; Funding acquisition: Cristina Rodríguez-Padilla; Investigation: Pablo Zapata-Benavides, Santiago Saavedra-Alonso; Methodology: Fernanda Guadalupe Thompson-Armendariz, José Luis Zacarias-Hernández; Manuscript writing: All Authors; Final approval of manuscript: All Authors.

\section{Acknowledgements}

The present study was supported by research grant CB-182231 from Consejo Nacional de Ciencia y Tecnología (CONACYT).

\section{References}

1 Zapata-Benavides P, Tuna M, Lopez-Berestein G and Tari A: Down-regulation of Wilms' tumor 1 protein inhibits breast cancer proliferation. Biochem Biophys Res Comm 295: 784-790, 2002. PMID: 12127961. DOI: 10.1016/S0006-291X(02)00751-9.

2 Englert C, Maheswaran S and Garvin AJ: Induction of p21 by the Wilms' tumor suppressor gene. Cancer Res 57: 1429-1434, 1997. PMID: 9108440.

3 Miyoshi Y, Ando A, Egawa C, Taquchi T, Tamaki Y, Tamaqui H, Sugiyama H and Noquchi S: High expression of Wilms' tumor suppressor gene predicts poor prognosis in breast cancer patients. Clin Cancer Res 8: 1167-1171, 2002. PMID: 12006533.

4 Koesters R, Linnebacher M, Coy JF, Germann A, Schwitalle Y, Findeisen P and Doeberitz MVK: WT1 is a tumor-associated antigen in colon cancer that can be recognized by in vitrostimulated cytotoxic T-cells. Int J Cancer 109: 385-392, 2004. PMID: 14961577. DOI: 10.1002/ijc.11721.

5 Stewart CJR, Brennan BA, Chan T and Netreba J: WT1 expression in endometrioid ovarian carcinoma with and without associated endometriosis. Pathology 40: 592-599, 2008. PMID: 18752126. DOI: 10.1080/00313020802320697.

6 Wilsher M and Cheerala B: WT1 as a complementary marker of malignant melanoma: An immunohistochemical study of whole sections. Histopathology 51: 605-610, 2007. PMID: 17927581 DOI:10.1111/j.1365-2559.2007.02843.x.

7 Oji Y, Miyoshi S, Maeda H, Hayashi S, Tamaki H, Nakatsuka S, Yao M, Takahashi E, Nakano Y, Hirabayashi H, Shintani Y, Oka Y, Tsuboi A, Hosen N, Asada M, Fujioka T, Murakami M, Kanato
K, Motomura M, Kim EH, Kawakami M, Ikegame K, Ogawa H, Aozasa K, Kawase I and Sugiyama H: Overexpression of the Wilms' tumor gene WT1 in de novo lung cancers. Int J Cancer 100: 297-303, 2002. PMID: 12115544. DOI: 10.1002/ijc.10476.

8 Qin YZ, Wang Y, Zhu HH, Gale RP, Zhang MJ, Jiang Q, Jiang $\mathrm{H}$, Xu LP, Chen H, Zhang XH, Liu YR, Lai YY, Jiang B, Liu KY and Huang XJ: Low WT1 transcript levels at diagnosis predicted poor outcomes of acute myeloid leukemia patients with $\mathrm{t}(8 ; 21)$ who received chemotherapy or allogeneic hematopoietic stem cell transplantation. Chin J Cancer 35: 46, 2016. PMID: 27197573. DOI: 10.1186/s40880-016-0110-6.

9 Kornegoor R, Moelans CB, Verschuur-Maes AHJ, Hogenes MC, de Bruin PC, Oudejans JJ, Marchionni L and van Diest PJ: Oncogene amplification in male breast cancer: Analysis by multiplex ligation-dependent probe amplification. Breast Cancer Res Treat 135: 49-58, 2012. PMID: 22527098. DOI:10.1007/ s10549-012-2051-3.

10 Inoue K, Sugiyama H, Ogawa H, Nakagawa M, Yamagami T, Miwa H, Kita K, Hiraoka A, Masaoka T and Nasu K: WT1 as a new prognostic factor and a new marker for the detection of minimal residual disease in acute leukemia. Blood 84: 30713079, 1994. PMID: 7949179.

11 Wu C, Wang Y, Xia Y, He S, Wang Z, Chen Y, Wu C, Shu Y and Jiang J: Wilms' tumor 1 enhances cisplatin-resistance of advanced NSCLC. FEBS Lett 588: 4566-4572, 2014. PMID: 25447528. DOI: 10.1016/jfebslet.2014.10.026.

12 Zidanloo SG, Colagar AH, Ayatollahi H and Raoof JB: Downregulation of the WT1 gene expression via TMPyP4 stabilization of promoter G-quadruplexes in leukemia cells. Tumor Biol 37: 9967-9977, 2016. PMID: 26815508. DOI: 10.1007/s13277-0164881-9.

13 Tangudu NK, Verma VK, Clemons TD, Beevi SS, Hay T, Mahidhara G, Raja M, Nair RA, Alexander LE, Patel AB, Jose J, Smith NM, Zdyrko B, Bourdoncle A, Luzinov I, Iyer KS, Clarke AR and Dinesh Kumar L: RNA interference using cMyc-conjugated nanoparticles suppresses breast and colorectal cancer models. Mol Cancer Ther 14: 1259-1269, 2015. PMID: 25695957 DOI: 10.1158/1535-7163.MCT-14-0970.

14 Hung MS, Chen IC, You L, Jablons DM, Li YC, Mao JH, Xu Z, Lung JH, Yang CT and Liu ST: Knockdown of cullin 4A inhibits growth and increases chemosensitivity in lung cancer cells. J Cell Mol Med 20: 1295-1306, 2016. PMID: 26969027. DOI: $10.1111 /$ jcmm.12811.

15 Maduri S: Applicability of RNA interference in cancer therapy: Current status Superior vena cava syndrome: Initial presentation of acute myeloid leukemia in a child. Indian J Cancer 52: 11, 2015. PMID: 26837961. DOI: 10.4103/0019-509X.175592.

16 Huang Z, Lei X, Zhong M, Zhu B, Tang S, Liao D and Park BH: BCL2 small interfering RNA sensitizes cisplatin-resistant human lung adenocarcinoma A549/DDP cell to cisplatin and diallyl disulfide. Acta Biochim Biophys Sinica 39: 835-843, 2007. PMID: 17989874. DOI:10.1111/j.1745-7270.2007.00356.x.

17 Lei X, Huang Z, Zhong M, Zhu B, Tang S and Liao D: BCL-XL small interfering RNA sensitizes cisplatin-resistant human lung adenocarcinoma cells. Acta Biochim Biophys Sinica 39: 344350, 2007. PMID: 17492131. DOI: 10.1111/j.1745-7270.2007. 00286.x.

18 Singh MS and Peer D: RNA nanomedicines: The nextgeneration drugs? Curr Opin Biotechnol 39: 28-34, 2016. PMID: 26773301. DOI: 10.1016/j.copbio.2015.12.011. 
19 Zamora-Avila DE, Franco-Molina MA, Trejo-Avila LM, RodríguezPadilla C, Resendez-Perez D and Zapata-Benavides P: RNAi silencing of the WT1 gene inhibits cell proliferation and induces apoptosis in the B16F10 murine melanoma cell line. Melanoma Res 17: 341-348, 2007. PMID: 22740987. DOI: 10.3892/ol.2012.578.

20 Tatsumi N, Oji Y, Tsuji N, Higashio M, Aoyagi S, Fukuda I, Ito K, Nakamura J, Takashima S, Kitamura Y, Miyai S, Jomgeow T, Li Z, Shirakata T, Nishida S, Tsuboi A, Oka Y and Sugiyama H: Wilms' tumor gene WT1-shRNA as a potent apoptosis-inducing agent for solid tumors. Int J Oncol 32: 701-712, 2008. PMID: 18292948. DOI: 10.3892/ijo.32.3.701.

$21 \mathrm{Lv}$ L, Chen G, Zhou J, Li J and Gong J: WT1-AS promotes cell apoptosis in hepatocellular carcinoma through down-regulating of WT1. J Exp Clin Cancer Res 34: 119, 2015. PMID: 26462627, DOI: $10.1186 / \mathrm{s} 13046-015-0233-7$.

22 Zamora-Avila DE, Zapata-Benavides P, Franco-Molina MA, Franco-Molina MA, Saavedra-Alonso S, Trejo-Avila LM, Resendez-Perez D, Mendez-Vázquez JL, Isaias-Badillo J and Rodríguez-Padilla C: WT1 gene silencing by aerosol delivery of PEI-RNAi complexes inhibits B16-F10 lung metastases growth. Cancer Gene Ther 16: 892-899, 2009. PMID: 19461674. DOI: 10.1038/cgt.2009.35.

23 Zapata-Benavides P, Manilla-Muñoz E, Zamora-Avila DE, Saavedra-Alonso S, Franco-Molina MA, Trejo-Avila LM, Davalos-Aranda G and Rodríguez-Padilla C: WT1 silencing by RNAi synergizes with chemotherapeutic agents and induces chemosensitization to doxorubicin and cisplatin in B16F10 murine melanoma cells. Oncol Lett 3: 751-755, 2012. PMID: 2274987. DOI: 10.3892/ol.2012.578.

24 Peters GJ, Van Moorsel CJ, Lakerveld B, Smid K, Noordhuis P, Comijn EC, Weaver D, Willey JC, Voorn D, Van der Vijgh WJ and Pinedo HM: Effects of gemcitabine on cis-platinum-DNA adduct formation and repair in a panel of gemcitabine and cisplatin-sensitive or -resistant human ovarian cancer cell lines. Int J Oncol 28: 237-244, 2006. PMID: 16328001. DOI: 10.3892/ijo.28.1.237

25 Crino L, Scagliotti G, Marangolo M, Figoli F, Clerici M, De Marinis F, Salvati F, Cruciani G, Dogliotti L, Pucci F, Paccagnella A, Adamo V, Altavilla G, Incoronato P, Trippetti M, Mosconi AM, Santucci A, Sorbolini S, Oliva C and Tonato M: Cisplatin-gemcitabine combination in advanced non-small-cell lung cancer: A phase II study. J Clin Oncol 15: 297-303, 1997. PMID: 8996156. DOI: 10.1200/JCO.1997.15.1.297.

26 Ouyang G, Liu Z, Huang S, Li Q, Xiong L, Miao X and Wen Y: Gemcitabine plus cisplatin versus gemcitabine alone in the treatment of pancreatic cancer: A meta-analysis. World J Surg Oncol 14: 59, 2016. PMID: 26927942. DOI: 10.1186/s12957016-0813-9.

27 Kosh N, Quispe D, Shi R, Mansour R and Burton GV: Cisplatin-gemcitabine therapy in metastatic breast cancer: Improved outcome in triple-negative breast cancer patients compared to non-triple-negative patients. Breast 19: 246-248, 2010. PMID: 20227277. DOI: 10.1016/j.breast2010.02.003.

28 Laux DE, Curran EM, Welshons WV, Lubahn DB and Huang TH: Hypermethylation of the Wilms' tumor suppressor gene $\mathrm{CpG}$ island in human breast carcinomas. Breast Cancer Res Treat 56: 35-43, 1999. PMID: 10517341.

29 Antunes F, Corazzari M, Pereira G, Fimia GM, Piacentini M and Smaili S: Fasting boosts sensitivity of human skin melanoma to cisplatin-induced cell death Biochem Biophys Res Commun
485: 16-22, 2017. PMID: 27693581. DOI: 10.1016/ j.bbrc.2016.09.149.

30 Linardou H, Pentheroudakis G, Varthalitis I, Gogas H, Pectasides D, Makatsoris T, Fountzilas G and Bafaloukos D: Predictive biomarkers to chemotherapy in patients with advanced melanoma receiving the combination of cisplatinvinblastine-temozolomide (PVT) as first-line treatment: A study of the Hellenic Cooperative Oncology Group (HECOG). Anticancer Res 35: 1105-1113, 2015. PMID: 25667500.

31 Wang D and Lippard SJ: Cellular processing of platinum anticancer drugs. Nat Rev Drug Discov 4: 307-320, 2005. PMID: 15789122. DOI: 10.1038/nrd1691.

32 Bergman AM, Pinedo HM and Peters GJ: Determinants of resistance to 2',2'-difluorodeoxycytidine (gemcitabine). Drug Resist Updat 5: 19-33, 2005. PMID: 12127861. DOI: 10.1016/S1368-7646(02)00002-X.

33 Babu A, Munsh A and Ramesh R: Combinatorial therapeutic approaches with RNAi and anticancer drugs using nanodrug delivery systems. Drug Dev Ind Pharm 1-1, 2017. PMID: 28523942. DOI: 10.1080/03639045.2017.1313861.

34 Densmore CL, Kleinerman ES, Gautam A, Jia SF, Xu B, Worth LL, Waldrep JC, Fung YK, T'Ang A and Knight V: Growth suppression of established human osteosarcoma lung metastases in mice by aerosol gene therapy with PEI-p53 complexes. Cancer Gene Ther 8: 619-27, 2001. PMID: 11593330. DOI: 10.1038/sj.cgt.7700343.

35 Gautam A, Densmore CL, Melton S, Golunski E and Waldrep JC: Aerosol delivery of PEI-p53 complexes inhibits B16-F10 lung metastases through regulation of angiogenesis. Cancer Gene Ther 9: 28-36, 2002. PMID: 11916242. DOI: 10.1038/ sj.cgt.7700405.

36 Qin Q, Lin YW, Zheng XY, Chen H, Mao QQ, Yang K, Huang SJ and Zhao ZY: RNAa-mediated overexpression of WT1 induces apoptosis in HepG2 cells. World J Surg Oncol 10: 11, 2012. PMID: 22244202. DOI: 10.1186/1477-7819-10-11.

37 Loeb DM: WT1 influences apoptosis through transcriptional regulation of BCL2 family members. Cell Cycle 5: 1249-1253, 2006. PMID: 16760668. DOI: 10.4161/cc.5.12.2807.

38 Mayo MW, Wang CY, Drouin SS, Madrid LV, Marshall AF, Reed JC, Weissman BE and Baldwin AS: WT1 modulates apoptosis by transcriptionally upregulating the BCL2 protooncogene. EMBO J 18: 3990-4003, 1999. 1999. PMID: 10406804. DOI: 10.1093/emboj/18.14.3990.

39 Koido S, Kan S, Yoshida K, Yoshizaki S, Takakura K, Namiki Y, Tsukinaga S, Odahara S, Kajihara M, Okamoto M, Ito M, Yusa S, Gong J, Sugiyama H, Ohkusa T, Homma S and Tajiri H: Immunogenic modulation of cholangiocarcinoma cells by chemoimmunotherapy. Anticancer Res 34: 6353-6361, 2014. PMID: 25368235.

40 Takahara A, Koido S, Ito M, Nagasaki E, Sagawa Y, Iwamoto T, Komita H, Ochi T, Fujiwara H, Yasukawa M, Mineno J, Shiku H, Nishida S, Sugiyama H, Tajiri H and Homma S: Gemcitabine enhances Wilm's tumor gene WT1 expression and sensitizes human pancreatic cancer cells with WT1-specific T-cellmediated antitumor immune response. Cancer Immunol Immunother 60: 1289-1297, 2011. PMID: 21607557. DOI: 10.1007/s00262-011-1033-3.

Received January 14, 2019

Revised February 2, 2019

Accepted February 7, 2019 